\title{
Can Energy Management Systems Improve the Performance of Industrial Enterprises?
}

\author{
Rong Liu ${ }^{1}$, Feng $\mathrm{He}^{1 *}$, Lili Chen ${ }^{2}$ \\ ${ }^{1}$ School of Economics and Management, University of Science and Technology Beijing, Beijing 100083, China \\ ${ }^{2}$ School of International Economics and Management, Beijing Technology and Business University, \\ Beijing 100048, China
}

Received: 19 November 2020

Accepted: 24 March 2021

\begin{abstract}
At present, China is the world's largest energy consuming country and industrial manufacturing country, especially industrial enterprises are the main energy consumers. The steel industry occupies an important position in China's national economy, and has the characteristics of high energy consumption, high pollution and high emissions. Therefore, based on the perspective of energy management, this paper selects 54 large-scale steel companies from China Iron and Steel Association from 2009 to 2017 as a sample, and applies the SBM super-efficiency model that includes undesired output and the differences-in-differences (DID) method to explore the impact of companies implementing energy management systems on corporate performance. The empirical results show that: the implementation of energy management system has a positive impact on enterprise performance. Moreover, the impact of energy management system on economic performance is greater than that on environmental performance. Through the analysis of regional heterogeneity and ownership heterogeneity, it is further found that the implementation of energy management system in eastern region enterprises and stateowned enterprises has a more obvious impact on enterprise performance. The results of this paper can encourage those managers who want to apply energy management system in enterprises to achieve sustainable development, so as to improve the efficiency and results of energy management.
\end{abstract}

Keywords: energy management system (EnMS), iron and steel enterprises, enterprise performance

\section{Introduction}

Energy is an important material basis for national economic and social development. Since 2010, China has replaced the United States as the world's largest energy consumer [1]. However, China's per capita energy share is far below the world average level, and

*e-mail: hefeng@manage.ustb.edu.cn the lack of energy supply has become an important factor restricting the sustainable development of social economy. At present, China is in the development stage of high-speed industrialization and urbanization. At this stage, it is still an extensive economy. The energy utilization efficiency is low and the energy consumption is high. The serious waste of energy is very serious. The shortage of energy has caused great pressure on China's resource shortage and environmental governance. With the impact of energy crisis, environmental protection and other factors, the effective use of energy has become 
an important factor affecting the economic efficiency and sustainable development of various industries.

Industry is the main user of energy. With the increasing shortage of fossil fuels and climate change caused by environmental pollution, energy efficiency has become increasingly important to the industrial sector. Although all industrial sectors have continued to improve their energy performance in the past 30 years, there is still a lot of potential for energy efficiency to be developed [2]. As the micro main body of the market, enterprises are the direct undertaker of production and the main energy consumers. The energy waste and environmental pollution caused by the low energy utilization efficiency of enterprises have become a global concern. Therefore, the enterprise management and operation of the industrial sector should be incorporated into the energy management framework. Enterprise energy management is conducive to improve energy efficiency, promote energy conservation and reduce the impact on the external environment. Especially in the energy intensive industries such as steel, petrochemical, cement and papermaking, correct and efficient energy management is needed.

In order to improve energy efficiency and implement more energy-saving and environment-friendly management mode, the International Organization for Standardization (ISO) has launched the energy management system ISO 50001. The construction of energy management system in accordance with standards can promote enterprises to adopt advanced energy management methods and the best practice of energy conservation and emission reduction. The goal is to effectively reduce energy consumption, improve energy utilization efficiency, and continuously improve its energy management performance, reduce energy costs and reduce adverse effects on the environment.

China is the largest developing country in the world. The steel industry is one of the main contributors to China's economic growth. China's share of world steel production has increased from less than $20 \%$ to more than $50 \%$ [3]. However, this rapid development is driven by the energy-intensive mode, which leads to a series of environmental problems. Many Chinese iron and steel enterprises have a negative impact on the environment in the process of production and operation [4]. For large iron and steel enterprises, the throughput of raw materials and fuel is large, with the characteristics of high consumption, high pollution and high emission. The energy cost of iron and steel enterprises is the largest cost besides the cost of raw materials. Therefore, it is of great significance to study the energy management of Chinese iron and steel enterprises.

As far as we know, recent quantitative studies on management systems have paid more attention to the benefits of adopting environmental management systems (EMS) [5-8], while ignoring the impact of energy management system (EnMS) on enterprise performance. More importantly, although the energy management system maintains a close relationship with the environmental management system, it emphasizes continuous improvement of energy performance. In an organization with high energy costs (such as the steel industry), it is more appropriate to study energy management systems.

Therefore, the purpose of this paper is to study the impact of energy management system on the performance of Chinese steel enterprises. In other words, this paper discusses whether the implementation of energy management system will have a positive impact on the economy and the environment. We hope that the research results can provide some theoretical and practical reference for iron and steel enterprises to achieve performance optimization. In addition, as China's steel production accounts for a huge share of world steel production, environmental research based on China's steel industry can provide theoretical and practical significance for formulating and implementing environmental policies for steel industry in other emerging economies.

\section{Research Hypotheses}

So far, the conceptual and empirical studies on the impact of energy management systems are very limited [9-11]. The research community has analyzed energy management systems and the applicability and effectiveness of standards for such systems from both conceptual and empirical perspectives $[10,12,13]$. However, for business managers and policy makers, it is of great interest to prove that the implementation of energy management system standards can improve enterprise performance.

\section{Energy Management System}

Energy management in the industrial field is a basic business problem, from simple equipment replacement to more comprehensive energy management method, and finally to the implementation of energy management system [14]. On June 15, 2011, the international organization for Standardization (ISO) released ISO 50001 for energy management, which has been widely used worldwide [11]. The energy management system standard is a set of management standards used to regulate the organization's energy management, aiming to reduce the organization's energy consumption, improve energy efficiency and solve related environmental problems. But ISO 50001 is not the world's first energy management standard. Earlier, there were about 14 regional or local energy management standards (including China).

Regarding China's energy management standards, starting in 2002, after years of research by relevant institutions and experts, China has gradually explored and established a series of standards for China's energy management system. In 2009, China's energy management system standards were issued and implemented earlier than the international energy 
management system standards. In 2011, China's energy management system standard GB/T 23331-2012 “energy management system requirements" was issued, which is equivalent to the requirements of ISO 50001:2011. The system maintains a high consistency with the ISO 50001 energy management system standard, and China's energy management system standard is in line with international standards.

Research shows that the implementation of energy management system can obtain many benefits $[15,16]$. The purpose of EnMS is to make production activities in the industrial sector more efficient in terms of energy use. Energy efficiency seeks to use less energy to reduce financial costs, operating costs, resource use and waste emissions without damaging revenue [17]. The adoption of EnMS is the basis for continuous improvement of energy efficiency in the company's production process [18]. Therefore, no matter from the economic benefits or the harm to the environment, enterprises should actively implement the EnMS.

At present, most enterprises have realized the important role of energy management system in reducing enterprise cost, increasing income, saving energy and reducing consumption. However, the practice and promotion process of energy management system is not smooth. The main reasons are as follows: (1) the policies formulated by the government can not meet the requirements of enterprises, and it is difficult to implement them; (2) enterprises are lack of funds and talents, and can not see the obvious benefits brought by the EnMS in a short time. The lack of awareness of the importance of enterprise energy management is the main problem faced by many enterprises, resulting in the low willingness of enterprises to apply EnMS. At present, most scholars' research on EnMS is mainly focused on the establishment, operation, and reform ideas of the system, and they have seldom explored the problems in the application process. Whether the application of EnMS can effectively save energy, reduce consumption and protect the environment needs to be verified by empirical research.

Once the energy management system standards are well established and disseminated among different departments and geographic regions, it is necessary to analyze the differences between adopters and non-adopters. This will clarify that the standard's contribution to the adopting organization will not only arouse the interest of managers, but also of government agencies and organizations that specialize in energy management system certification [11]. Therefore, this paper uses the differences-in-differences (DID) method to study whether the implementation of energy management system affects enterprise performance.

\section{Research Hypothesis}

Ates and Durakbasa pointed out that in countries with high energy intensity, the transition from traditional energy use to standardized energy management is accelerating [19]. Schulze et al. emphasized in an overview of industrial energy management that one of the most promising ways to reduce energy consumption and energy costs is to implement energy management [2]. Porzio et al. found that environmental demands and desire for higher profits in the steel industry have promoted energy management in enterprises [20].

Energy management system is an important tool and method adopted by the industrial sector [21], which can improve efficiency [22], reduce costs [23] and reduce the adverse impact on the environment [24]. At present, scholars have studied EnMS from different angles. Lee et al. conducted a comprehensive test on EnMS of 305 enterprises and proved that integrating energy management systems into corporate management can greatly improve overall energy efficiency [25]. Konstantin et al. introduced an advanced energy management framework that can provide decision makers at all production levels with real-time information about the energy performance of the production system, thereby supporting effective strategic and operational decisions [26]. Some scholars believe that optimizing energy management is an important prerequisite for ensuring the economic feasibility of energy conservation and emission reduction for enterprises [27]. António et al. conducted a detailed analysis and evaluation of the effectiveness of the implementation of the energy management system from the perspective of sustainable development, determined the existence of gaps, and developed improvement measures that can fill the gaps [15]. Through some case studies, Chiu et al. analyzed that the implementation of ISO 50001 has improved the energy performance of enterprises. These good results also encourage competitors to implement the standard [28].

The dissemination process of energy management system standards may be affected by the environmental, economic and social cultural factors of each region, country and industrial sector [29]. In recent years, the implementation of EnMS has enabled organizations around the world to achieve energy performance improvements, helping enterprises achieve environmental regulations, economic benefits, and improve competitiveness [30]. Marimon et al. studied 87 Spanish companies that have obtained ISO 50001 certification through questionnaire survey, and found that the establishment of an EnMS standard can bring ecological and operational benefits to enterprises [11]. As far as the EnMS is concerned, it is expected that companies that have obtained standardized certification will have higher energy efficiency and reduce adverse environmental impacts. However, this relationship is still not well established, and the implementation effect of EnMS is still being questioned [24, 31]. Moreover, enterprises are not very enthusiastic about implementing EnMS [32], and there are still some difficulties in implementing EnMS [33]. Enterprises may simply show that they have implemented an energy management 
system to please external stakeholders (for example, customers, government regulatory agencies, etc.) without realizing the true value of EnMS. Therefore, evaluating the impact of the energy management system on the economic and environmental performance of a enterprises can help enterprises understand the reasons for energy management and encourage senior managers to actively implement EnMS. Therefore, the research hypothesis is proposed:

Hypothesis H1. The implementation of an energy management system by an enterprise can prompt the enterprise to realize a cost-saving and environmentally friendly production model, thereby improving enterprise performance.

\section{Economic Aspect}

Currently, the main reason why business decision makers are reluctant to invest in EnMS is that EnMS is not considered a profitable investment. The time and cost associated with the development, implementation and certification process of EnMS is relatively high and is considered an expense rather than an investment [34]. This idea is still prevalent in the global industrial enterprises. Some scholars have conducted research on 120 listed companies in order to understand the economic impact of energy management system certification on corporate performance. They found that the negative effects were negative, but the results were not statistically significant [35].

It is estimated that in some energy-intensive industries (EII), energy costs account for more than $30 \%$ of the final production cost [24]. The rising prices of energy sources such as oil, electricity, coal and natural gas have had a huge impact on the economic performance of the manufacturing industry, but at the same time it has also prompted enterprises to improve energy efficiency and save energy costs. The main driving forces that promote the decline of energy costs of enterprises include: the trend of rising energy prices, the increasing regulatory requirements in the energy and environmental fields, and the pressure of energy policies [2]. The implementation of EnMS to reduce energy consumption in the industrial sector is considered to be one of the most effective strategies to improve competitiveness and increase income.

The EnMS is a system that strengthens the standardization of energy management of industrial enterprises, and aims to improve energy utilization efficiency to reduce the energy costs of enterprises, thereby increasing their economic benefits. Through the implementation of the EnMS, the energy costs of enterprises have been reduced, and the benefits have increased to a certain extent. This view has been verified by many scholars [36]. Karcher and Jochem found that the positive results of the energy management system in saving money motivate organizations to implement it [37]. Research by McKane et al. proved that the energy management system saves money for industrial enterprises [38]. Wagner conducted a study on energy management of 118 EU enterprises and found that more than $90 \%$ of the enterprises engaged in energy management have achieved benefit growth [39]. In addition to reducing energy costs, the implementation of energy management systems can also reduce the cost burden of carbon taxes and other emission payment schemes (such as sewage charges) [12]. Through the implementation of EnMS, enterprises can better enter certain markets and realize product differentiation. Through the implementation of energy management system standards, enterprises can obtain certification, which will improve their public image, reduce the regulatory risk of the government, maintain the legitimacy of enterprises, reduce the payment of polluters, and thus maintain lower costs. In order to allow their products to enter the more exclusive market, further improve the economic performance of enterprises [34]. In order to explore the impact of energy management system on enterprise economic performance. The following hypotheses are proposed:

Hypothesis H2. The implementation of energy management system can promote the economic performance of enterprises.

\section{Environmental Aspect}

Environmental protection is currently one of the most widely known topics. As society's demand for sustainable actions continues to increase, especially with regard to waste emissions and climate change, superior energy efficiency may become a source of competitive advantage [24]. In the past 15 years, China, the European Union, the United States and many other countries have introduced many energy regulations and economic incentives. The increase and strengthening of environmental regulations force organizations to reduce their impact on the environment [34]. Although the Chinese government's environmental supervision and related laws have increased in recent years, compared with Western developed countries, Chinese enterprises are still in the early stages of environmental protection. Senior managers of Chinese enterprises have not shown a positive attitude towards environmental issues [40].

Konstantin et al. pointed out that energy consumption continues to grow, environmental regulations are constantly updated, and energy security has attracted much attention. These status quo have forced the entire EU and the world to commit to improving the energy efficiency of industrial enterprises. In recent years, energy costs have continued to rise, and waste water, waste gas, and waste residues discharged in the process of energy consumption have caused great harm to the environment [41]. Therefore, in order to enhance the competitiveness of industries and improve the global environment, it is very important for industrial enterprises to implement 
EnMS. Sousa et al. described the spread of EnMS standards around the world through research and the main factors that determine the adoption of EnMS in different regions of the world. The study found that the focus on climate change is the main factor that determines the adoption of EnMS by companies in most countries/regions [9]. Research by Tseng et al. found that cloud energy management system (cloud EnMS) has brought energy-saving and environmental benefits to small and medium-sized enterprises in Taiwan [42]. Some scholars have conducted an in-depth analysis of how the Serbian manufacturing industry implements energy management. The study concluded that it is necessary for Serbia to implement EnMS to reduce energy consumption and carbon dioxide emissions [43]. Chrysikopoulos et al. proposes a practical framework based on the EnMS. The implementation of this framework will bring low-carbon economy and environmental benefits to the organization [44]. The success of EnMS lies in reducing the energy cost and environmental problems without affecting the production and quality of industrial enterprises. In order to explore the impact of EnMS on enterprise environmental performance. The following hypotheses are proposed:

Hypothesis H3. The implementation of energy management system can promote the environmental performance of enterprises.

The main purpose of the implementation of the EnMS is to improve energy utilization efficiency, guide enterprises to handle the relationship between energy consumption and economic and social development, promote green development, promote enterprises to reduce pollutant emissions, and achieve high-quality development.

The structure of the paper is as follows. Section 2 presents an overview of related literature and formulates research hypotheses. Section 3 describes the data, sample selection and measurement of the dependent variable. Sections 4 present estimation approach and variables. Sections 5 present the empirical results. Section 6 discusses the findings and concludes. It also outlines the limitations of the research and proposes future research prospects.

\section{Material and Methods}

\section{Data and Sample Selection}

Effective industrial energy management is often highly environmentally specific because it depends on many local factors, such as product design, process selection, etc. This means that it is difficult to compare energy management solutions between different industries [41], otherwise it will lead to deviations in research results. Since November 1, 2009, the China Certification and Accreditation Administration (CNCA) officially launched the pilot work of energy management system certification. Iron and steel enterprises are listed as the top ten pilot industries for energy management system certification. Due to the important position and role of the iron and steel industry in the development of China's national economy, the increasing attention of steel enterprises to energy efficiency and the continuous advancement of China's energy management, Chinese steel enterprises have become suitable groups for studying energy management systems. As an important high-pollution, high-energy consumption, and highemission industry in China, steel enterprises have long been required to reduce pollution emissions and improve efficiency. Christoffersen et al. research shows that large enterprises are more conducive to the realization of enterprise energy management than small enterprises, and energy intensive enterprises are more active in implementing energy management [45]. Therefore, the research object of this paper is China's large-scale iron and steel enterprises. And taking a single industry as the research object can effectively eliminate the noise interference produced by different industries [46]. This paper comprehensively considers the principles of data availability, comprehensiveness, and representativeness, and selects data from 54 large-scale iron and steel enterprises in the China Iron and Steel Industry Association (CISA) from 2009 to 2017.

\section{Measuring Enterprise Performance}

Does energy management system promote the sustainable development of economic and environmental benefits of iron and steel enterprises? To prove the contribution of the energy management system to the enterprise, it is necessary to consider both economic and environmental aspects. While attaching importance to improving the internal economic benefits of industrial enterprises, we must also attach importance to the impact of energy utilization on the environment, so as to truly realize the overall sustainable development of energy, economy, and environment. The energy management system should take high-efficiency energy utilization, good economic indicators and low-intensity pollutant emissions as its main goals. Therefore, it is not enough to rely on a single index when evaluating the economic and environmental benefits of their enterprises. Existing measurement methods have certain limitations and lack a comprehensive evaluation of the energy management benefits of enterprises. Many studies only use one or one type of economic benefit indicators and environmental pollution indicators, and most of them use relatively simple and indirect measurement methods, failing to fully demonstrate enterprises performance. Therefore, it is necessary to adopt a comprehensive evaluation analysis of multiple indicators. This study will use the data envelopment analysis (DEA) method to measure corporate performance and consider the input and output of multiple indicators to help establish objective evaluation standards. 


\section{Measurement Methods}

The original DEA model measures the efficiency score of the decision-making unit (DMU) based on input and ideal output (such as income, profitability). When it comes to environmental efficiency and pollution such as greenhouse gas emissions, waste water, solid waste and other pollution, the traditional method of only considering the expected output is no longer applicable. In order to overcome the limitations of the original data envelopment analysis method, some scholars have proposed a data envelopment analysis method that includes undesired output. Due to the disadvantages and complexity of traditional DEA model configuration, Slack Based Model (SBM) has become the mainstream of current research [47]. The maximum efficiency value obtained by the standard DEA model is 1 , and the effective DMU efficiency value is the same, and the efficiency of these effective DMUs cannot be further distinguished. In order to solve this problem, Andersen and Petersen proposed a method to further distinguish the degree of effectiveness of effective DMU. This method is called the "super efficiency" model. For the needs of further research in this article, we combine the SBM model with undesired output and the "super efficiency" model. Form an SBM superefficiency model (super-SBM) that includes undesired output. The planning formula of the model is as follows:

$$
\begin{aligned}
& \min \rho=\frac{1+\frac{1}{m} \sum_{i=1}^{m} S_{i}^{-} / x_{i k}}{1-\frac{1}{q_{1}+q_{2}}\left(\sum_{r=1}^{q_{1}} S_{r}^{+} / y_{r k}+\sum_{t=1}^{q_{2}} S_{t}^{b-} / b_{t k}\right)} \\
& \text { S.t. } \quad \sum_{j=1, j \neq k}^{n} x_{i j} \lambda_{j}-S_{i}^{-} \leq x_{i k} \\
& \sum_{j=1, j \neq k}^{n} y_{i j} \lambda_{j}-S_{r}^{+} \geq y_{r k} \\
& \sum_{j=1, j \neq k}^{n} b_{t j} \lambda_{j}-S_{t}^{b-} \leq b_{t k} \\
& 1-\frac{1}{q_{1}+q_{2}}\left(\sum_{r=1}^{q_{1}} S_{r}^{+} / y_{r k}+\sum_{t=1}^{q_{2}} S_{t}^{b^{-}} / b_{t k}\right)>0 \\
& \lambda_{j}, S_{i}^{-}, S_{r}^{+} \geq 0 \\
& i=1,2, \ldots, m ; r=1,2, \ldots, q ; j=1,2, \Lambda, n(j \neq k) .
\end{aligned}
$$

In model (1), it is assumed that there are $\mathrm{n}$ decisionmaking units, and each decision-making unit has an input vector, an expected output vector and an undesired output vector. Assuming that there are $m$ types of inputs and $\mathrm{q}$ types of outputs, including $\mathrm{q}_{1}$ expected outputs and $\mathrm{q}_{2}$ undesired outputs, the input vector is $\mathrm{x} \in \mathrm{R}^{\mathrm{m}}$, the expected output vector is $\mathrm{y} \in \mathrm{R}^{\mathrm{ql}}$, and the undesired output vector is $b \in \mathrm{R}^{\mathrm{q}^{2}}$. Where $\mathrm{S}$ represents the slack of input and output, $\mathrm{S}^{-}$-represents the input redundancy, $\mathrm{S}^{+}$ represents the expected output shortage, $S^{b-}$ represents the undesired output excess, $\lambda$ is the weight vector, and $\rho$ represents the efficiency score.

\section{Description of Measurement Variables}

Due to the diversity and complexity of industrial processes, the formulation of suitable energy performance indicators also depends on the purpose of their application. Therefore, according to the situation of China's steel industry, we select the following indicators, as shown in Table 1.

Input variables include new water consumption, fixed assets, number of employees and energy consumption. Assets and labor are traditional input variables for research efficiency [48]. On this basis, this paper mainly studies the impact of energy management system on economic performance and environmental performance of iron and steel enterprises. Therefore, new water consumption and energy consumption variables are added to make the investment indicators more comprehensive. Industrial added value is considered as the best index to measure the economic performance of enterprises, so industrial value added is selected as the expected output variable to measure the economic performance of enterprises. The descriptive statistics of variables are shown in Table 2.

\section{Measurement Result}

This paper uses the SBM super-efficiency model that includes undesired output to calculate the input and output data of steel enterprises in terms of energy, economy and environment. The calculation results are represented by Score 1, Score 2 and Score 3. It provides objective and effective data for the following examination of the relationship between energy management system and enterprises economic performance and environmental performance. As shown in Fig. 1: Score 1-3 input variables are the same, but output variables are different. The output variables of Score 1 in the measurement process include industrial added value and undesired output variables, three wastes (waste, waste gas and wastewater) and sewage charges. The output variables of Score 2 in the measurement process include industrial added value and undesired output variables, three wastes (waste, waste gas and wastewater). During the measurement of Score 3, the output variables include industrial added value and undesired output variables sewage charges. Fig. 1 shows the measurement results from 2009 to 2017.

As can be seen from Fig. 1, the results of Score 1, Score 2 and Score 3 are significantly different. Therefore, it is reasonable for this study to separate the three wastes and sewage charges to measure the performance of steel enterprises.

The basic purpose of implementing EnMS is to: improve energy efficiency, reduce energy use and consumption; reduce energy costs, reduce greenhouse gas emissions and other related environmental impacts. The evaluation of economic and environmental benefits 
Table1. Variable selection and interpretation.

\begin{tabular}{|c|c|c|}
\hline Variable & & Interpretation \\
\hline \multirow[t]{4}{*}{ Inputs } & New water consumption & $=$ total water consumption $*(1-$ water resource reuse rate $)$ \\
\hline & Fixed assets & $\begin{array}{l}=\text { the original value of the fixed assets - the accumulated depreciation - the } \\
\text { provision for impairment of fixed assets }\end{array}$ \\
\hline & Number of employees & Average number of employees per year \\
\hline & Energy consumption & $\begin{array}{l}\text { A unified conversion of various energy consumption into standard coal con- } \\
\text { sumption }\end{array}$ \\
\hline \multirow[t]{4}{*}{ Undesirable outputs } & Waste residue & Total amount of waste residue produced by enterprises \\
\hline & Waste gas & Total amount of waste gas produced by enterprises \\
\hline & Waste water & Total amount of waste water produced by enterprises \\
\hline & Pollutant discharge fees & $\begin{array}{l}\text { Fees paid to the government according to the type, quantity and concentration } \\
\text { of pollutants discharged }\end{array}$ \\
\hline Expected output & Industrial added value & $\begin{array}{c}=\text { total industrial output value }- \text { industrial intermediate input }+ \text { value added tax } \\
\text { payable in the current period }\end{array}$ \\
\hline
\end{tabular}

can help the management to fully understand the good benefits of implementing EnMS. Therefore, when researching on EnMS, its comprehensive performance should be fully considered, including both economic performance and environmental performance. This paper uses the DEA model to combine economic performance and environmental performance, that is, to combine financial cost minimization and environmental improvement, and establish a comprehensive performance index, which is represented by Score 1 .

With the deepening of people's level of understanding, the impact of environmental benefits on industrial enterprises is increasing. Ecological drive is the strongest motivation for organizations to adopt EnMS, and some scholars' studies have also proved that adopting EnMS is very successful in bringing ecological benefits to the organizations that adopt it [11]. Therefore, this paper chooses waste water, waste gas and waste residue as environmental indicators to measure environmental performance, which is represented by Score 2 .
However, enterprises also have external motivations such as gaining competitive advantages and social requirements (pressure from government supervision), and whether the adoption of EnMS can bring economic benefits to enterprises. How the government's regulatory penalties affect the economic performance of industrial enterprises is also worthy of our in-depth discussion. Therefore, two indicators of industrial added value and pollutant discharge fees are included in the calculation of economic performance. This study uses Score 3 to represent economic performance.

\section{Methodology \\ Model Building}

The basic idea of the difference-in-difference method is to select the treat group that is affected by the policy change and the control group that is not affected by the policy change. By comparing the treatment group and the control group before and after the policy

Table 2. Descriptive statistics of input and output variables for iron and steel enterprises (2009-2017).

\begin{tabular}{|c|c|c|c|c|c|}
\hline Variable & Units & Mean & Std. dev. & Min & Max \\
\hline New water consumption & Ten thousand $\mathrm{m}^{3}$ & 2729.62 & 2198.23 & 228.56 & 11495.04 \\
\hline Fixed assets & Billion Yuan & 208.11 & 204.07 & 7.93 & 1177.92 \\
\hline Number of employees & Thousand people & 20.49 & 19.20 & 1.90 & 140.00 \\
\hline Energy consumption & Ten thousand tons & 438.11 & 344.00 & 24.51 & 2062.20 \\
\hline Waste residue & Ten thousand tons & 462.65 & 450.14 & 1.64 & 2682.52 \\
\hline Waste gas & Hundred million $\mathrm{m}^{3}$ & 1585.38 & 1423.30 & 0.06 & 7976.02 \\
\hline Waste water & Million $\mathrm{m}^{3}$ & 517.65 & 569.41 & 1.20 & 3760.80 \\
\hline Pollutant discharge fees & Million Yuan & 25.04 & 24.44 & 1.79 & 146.90 \\
\hline Industrial added value & Million Yuan & 5527.28 & 6356.22 & -4358.74 & 39911.30 \\
\hline
\end{tabular}




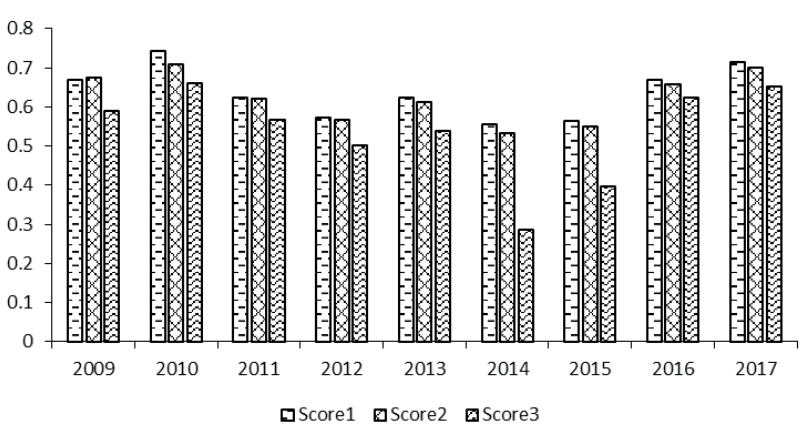

Fig. 1. Means of measurements from 2009 to 2017.

occurs to reflect the actual impact of policy variables on policy results.

The Chinese Energy Management System Standard GB/T 23331-2009 "Energy Management System Requirements" was issued and implemented in 2009. Therefore, whether enterprises have passed the certification of the EnMS can be regarded as a quasi-natural experiment, and the difference-indifference method is used to evaluate the economic and environmental performance of iron and steel enterprises. The research sample selected in this paper is 54 large iron and steel enterprises in China. Due to the difference in the time for enterprises to pass the energy management system certification, the value of 1 is assigned to the year that the enterprise passes the energy management system certification and thereafter, and the value is 0 before it passes the certification. Based on this, the dummy variable of the enterprise energy management system certification is directly generated.

This paper uses the certified EnMS dummy variable DID to construct a two-way fixed effect model for difference-in-difference estimation, and examines the impact of the energy management system on the economic performance and environmental performance of the enterprise. The specific model is set as follows:

$$
\begin{gathered}
\text { Score }_{i, t}=\beta_{0}+\beta_{1} \text { DID }_{i, t}+\beta_{2} \ln \text { Scale }_{i, t}+ \\
\beta_{3} \text { Fes }_{i, t}+\beta_{4} \operatorname{lnTC} C_{i, t}+\beta_{5} \ln M_{i, t} \\
+\beta_{6} \ln \operatorname{Leverage~}_{i, t}+\beta_{7} \operatorname{lnEPI} I_{i, t}+\theta_{i}+\gamma_{t}+\mu_{i, t}
\end{gathered}
$$

In the above model, $\mathbf{i}$ represents the enterprise and $\mathbf{t}$ represents the time (2009-2017). $\boldsymbol{\beta}_{0} \sim \boldsymbol{\beta}_{7}$ are parameters to be estimated. $\boldsymbol{\theta}_{\mathbf{i}}$ is the individual fixed effect of each enterprise, and $\gamma_{t}$ is the time fixed effect. $\boldsymbol{\mu}_{\mathrm{i}, \mathrm{t}}$ is the random disturbance term. Scale, Fes, TC, MBI, Leverage and EPI are a set of control variables.

\section{Variable Description}

In formula (1), Score $_{i, t}$ is the explained variable, which represents the enterprise performance of the $i$-th enterprise in the $t$ year. This paper selects expected output (industrial added value) and undesired output (including waste residue, waste gas, waste water and pollutant discharge fees) to measure the economic performance and environmental performance of the enterprise separately. Score 1 represents the comprehensive performance of iron and steel enterprises; Score 2 represents the environmental performance of iron and steel enterprises; and Score 3 represents the economic performance of iron and steel enterprises.

DID $_{i, t}$ represents a dummy variable for the certification of enterprise EnMS. In the formula (1), $\beta_{1}$ is the core estimation parameter, which represents the net effect of implementing standardized EnMS on enterprise performance. If $\beta_{1}$ is positive, it means that the implementation of energy management system is indeed conducive to promoting the improvement of enterprise performance. On the contrary, it has a restraining effect.

Control variables include enterprise scale (Scale), factor endowment structure (Fes), total operating cost (TC), main business income (MBI), year-end assetliability ratio (Leverage) and environmental protection investment (EPI). Enterprise scale (Scale) is measured

Table 3. Descriptive statistics of variables.

\begin{tabular}{|c|c|c|c|c|c|c|}
\hline Variable Name & Variable Symbol & Obs & Mean & Std. dev. & Min & Max \\
\hline Total performance & Score1 & 486 & 0.6375 & 0.2323 & 0.0798 & 1.2498 \\
\hline Environmental performance & Score2 & 486 & 0.6256 & 0.2451 & 0.0659 & 1.3331 \\
\hline Economic performance & Score3 & 486 & 0.5352 & 0.2976 & 0.035 & 1.6747 \\
\hline Dummy variable & DID & 486 & 0.1955 & 0.3966 & 0.0000 & 1.0000 \\
\hline Enterprise scale & $\operatorname{lnScale}$ & 486 & 15.0799 & 0.9477 & 11.9563 & 17.0061 \\
\hline Asset liability ratio & Leverage & 486 & 71.5757 & 13.5051 & 30.09 & 120.66 \\
\hline Factor endowment structure & Fes & 486 & 11.0906 & 8.1043 & 0.41 & 49.56 \\
\hline Total operating cost & $\operatorname{lnTC}$ & 486 & 14.9256 & 0.8490 & 12.0184 & 17.0088 \\
\hline Main business income & $\operatorname{lnMBI}$ & 486 & 14.8529 & 0.8702 & 11.9022 & 17.0223 \\
\hline Environmental protection investment & $\operatorname{lnEPI}$ & 486 & 8.7905 & 1.6043 & 3.2189 & 12.5022 \\
\hline
\end{tabular}


by the natural logarithm of total assets at the end of the year. The factor endowment structure (Fes) is expressed by the ratio of the company's net fixed assets to the company's annual average number of employees. The higher the factor endowment structure of the enterprise, the more capital-intensive the enterprise is, and the capital-intensive enterprise is more conducive to the improvement of production technology, thereby improving the enterprise performance. Total operating cost (TC) refers to the total cost of goods sold or services provided by an enterprise. Main business income (MBI) refers to the operating income obtained by the enterprise from the production and operation activities of the industry. This study also considers the impact of enterprise financial leverage on the enterprise, using the enterprise's year-end asset-liability ratio (Leverage) to measure enterprise financial leverage [49]. Environmental protection investment (EPI) refers to the amount of investment a company uses to protect the environment and reduce pollution. Table 3 presents the summary statistics for all variables.

\section{Results and Discussion}

\section{Basic Regression Analysis}

Since iron and steel enterprises have different characteristics in implementing energy management systems, it can be regarded as a quasi-natural experiment. Therefore, this paper uses the differencein-difference method to evaluate the impact of enterprises implementing energy management systems on enterprise performance. The specific empirical results are shown in Table 4.

In Table 4, model (1) - model (3) is the model without control variables, and model (4) - model (6) is regression analysis by adding control variables. The above three models are respectively the impact of the implementation of energy management system on the total performance, environmental performance and economic performance of enterprises. All estimation results show that whether the control variables are added or not, the regression coefficients of DID in this paper are significantly positive, indicating that the energy management system has a significant role in

Table 4. Regression analysis results.

\begin{tabular}{|c|c|c|c|c|c|c|}
\hline & (1) & (2) & (3) & (4) & (5) & (6) \\
\hline & Score1 & Score2 & Score3 & Score1 & Score2 & Score3 \\
\hline \multirow[t]{2}{*}{ DID } & $0.0620 *$ & $0.0725^{*}$ & $0.1054 * *$ & $0.0925 * * *$ & $0.1055^{* * *}$ & $0.1428 * * *$ \\
\hline & $(1.71)$ & $(1.90)$ & $(2.27)$ & $(2.93)$ & $(3.20)$ & $(3.50)$ \\
\hline \multirow[t]{2}{*}{ Scale } & & & & $-0.0942 * * *$ & $-0.0993 * * *$ & $-0.1158 * * *$ \\
\hline & & & & $(-4.93)$ & $(-4.97)$ & $(-4.69)$ \\
\hline \multirow[t]{2}{*}{ Leverage } & & & & $-0.0034 * * *$ & $-0.0040 * * *$ & $-0.0044 * * *$ \\
\hline & & & & $(-4.68)$ & $(-5.15)$ & $(-4.67)$ \\
\hline \multirow[t]{2}{*}{ Fes } & & & & $0.0046 * * *$ & $0.0047 * * *$ & $0.0058 * * *$ \\
\hline & & & & $(3.51)$ & $(3.41)$ & $(3.42)$ \\
\hline \multirow[t]{2}{*}{$\mathrm{TC}$} & & & & 0.0567 & 0.0594 & 0.0050 \\
\hline & & & & (1.03) & (1.03) & $(0.07)$ \\
\hline \multirow[t]{2}{*}{ MBI } & & & & $0.1107 * *$ & $0.1153 * *$ & $0.1920 * * *$ \\
\hline & & & & $(2.11)$ & $(2.10)$ & $(2.82)$ \\
\hline \multirow[t]{2}{*}{ EPI } & & & & 0.0012 & 0.0029 & 0.0056 \\
\hline & & & & (0.19) & $(0.43)$ & $(0.68)$ \\
\hline \multirow[t]{2}{*}{ cons } & $0.6318 * * *$ & $0.6189 * * *$ & $0.5254 * * *$ & -0.2574 & -0.2791 & $-0.4541^{*}$ \\
\hline & $(57.22)$ & (53.18) & $(37.23)$ & $(-1.28)$ & $(-1.32)$ & $(-1.74)$ \\
\hline Year & control & control & control & control & control & control \\
\hline Individual & control & control & control & control & control & control \\
\hline $\mathrm{N}$ & 486 & 486 & 486 & 486 & 486 & 486 \\
\hline $\mathrm{R}^{2}$ & 0.006 & 0.007 & 0.011 & 0.284 & 0.294 & 0.268 \\
\hline
\end{tabular}

Notes: $\mathrm{t}$ statistics in parentheses. ${ }^{* *}, * *$, and $*$ denote the statistical significance at the $0.01,0.05$, and 0.10 levels, respectively. 
promoting corporate performance. The results in Table 4 verify the hypothesis proposed in this paper.

Specifically, according to model (4), the influence coefficient of energy management system certification on the total performance of the enterprise is 0.0925 , which is significant at the level of $1 \%$, indicating that iron and steel enterprises promote the improvement of enterprise overall efficiency in the process of implementing EnMS. Then improve the performance of the enterprise, verifying the theoretical hypothesis 1 .

According to model (5), the influence coefficient of energy management system certification on environmental performance is 0.1055 , which is significant at the level of $1 \%$. That is, the energy management system certification promotes the improvement of enterprise environmental performance, which shows that the waste water, waste gas and waste residue discharged by enterprises in the process of energy consumption cause great harm to the environment. However, with the implementation of EnMS, enterprises reduce the emission of pollutants, promote the green development of enterprises, and promote the improvement of enterprise environmental performance, which verifies the hypothesis 3 .

According to model (6), the influence coefficient of enterprise energy management system certification on economic performance is 0.1428 , which is significant at the level of $1 \%$, that is, energy management system certification promotes the improvement of enterprise economic performance. Although enterprises will increase their costs in the process of implementing energy management system, the implementation of energy management system standards can reduce the energy cost of enterprises, improve the competitiveness of enterprises and increase the economic benefits of enterprises. In addition, the energy management system certification will improve the public's understanding of enterprises, reduce the regulatory risk of the government, maintain the legitimacy of enterprises, reduce pollution payment, and then maintain lower costs, so as to further promote the improvement of enterprise economic performance, which verifies the hypothesis 2 .

The regression results of control variables show that factor endowment structure (FES), total operating cost (TC), main business income (MBI) and environmental protection investment (EPI) contribute to the improvement of total performance, economic performance and environmental performance, among which factor endowment structure and main business income have significant promotion effect on enterprise performance; total operating cost and environmental protection investment have no significant promotion effect on enterprise performance. In addition, enterprise scale and asset liability ratio (Leverage) have a significant negative impact on enterprise total performance, economic performance and environmental performance, indicating that these two variables have a restraining effect on enterprise performance.

\section{Robustness Checks}

An important assumption for using the differencein-difference method to evaluate policy impact is that the treatment group and the control group have the same development trend before the policy is implemented. Therefore, it is necessary to conduct a common trend test on the research samples, and it is found that the development trend between the treatment group and the control group is consistent, and there is no systematic difference. The regression results in Table 4 show that energy management system certification has a significant role in promoting enterprise performance, which may be affected by other related industrial policies and enterprise development strategies. In order to further test the robustness of the regression results, the time for companies to obtain energy management system certification was changed to conduct a counterfactual test. That is to investigate the impact of dummy variable DID on enterprise performance when the enterprise fails to pass the energy management system certification. If the dummy variable DID does not have a significant impact on the enterprise performance, it means that before the enterprise passes the energy management system certification, there is indeed no conclusion that the energy management system certification has a significant effect on the enterprise performance, which means that there is no other systematic error in the basic regression results, and the conclusions drawn by the model in Table 4 are credible. If the dummy variable DID has a significant impact on enterprise performance, it shows that the improvement of enterprise performance may benefit from other factors, and the conclusion of Table 4 model is not credible. Therefore, this study will advance the time for enterprises to pass the energy management system certification by 2 years (DID-advance2) and 3 years (DID-advance3). The specific results are shown in Table 5.

In Table 5, models (7), (8) and (9) advance the time for enterprises to pass the energy management system certification by 2 years, and the models (10), (11) and (12) advance the time for enterprises to pass the energy management system certification by 3 years. The results show that energy management system certification has no significant impact on enterprise performance, which shows that the improvement of enterprise performance comes from the implementation of EnMS, rather than caused by other factors. Therefore, according to the basic regression model in Table 4, it is credible that the energy management system certification has a significant promoting effect on enterprise performance.

\section{Regional Heterogeneity Analysis}

For China, which has a vast territory, regions are faced with the problem of unbalanced and insufficient development, and the development level of each region is also different. So, is there any significant 
difference in the impact of energy management system certification on enterprise performance? According to the regional differences of enterprises, this study divides them into two parts: East and Mid-west. Therefore, this section analyzes the regional heterogeneity of the impact of energy management system certification on enterprise performance. The specific results are shown in Table 6.

By comparing the model (13), (14), (15) and model (16), (17), (18), it can be seen that the eastern region's enterprise energy management system certification has a significant promoting effect on enterprise performance, while the central and western region's enterprise energy management system certification has no statistically significant promoting effect on enterprise performance. And from the influence coefficient, the promotion effect of enterprise energy management system on enterprise performance in the eastern region is significantly higher than that in the central and western regions. This can be explained as: enterprises in the eastern region tend to obtain element resources more conveniently, with lower costs, higher quality of labor, more fierce competition among enterprises, and better government supervision. These reasons encourage enterprises to implement EnMS more actively, thus promoting the improvement of enterprise environmental performance and economic performance. The results also found that the inhibitory effect of enterprise scale on enterprise performance in the eastern region was significantly higher than that in the central and western regions.

\section{Ownership Heterogeneity Analysis}

There are many forms of ownership in China's iron and steel enterprises. According to the research samples, this study can be roughly divided into two categories: state-owned enterprises and non-state-owned enterprises. In China, the core difference between stateowned enterprises and non-state-owned enterprises

Table 5. Robustness test.

\begin{tabular}{|c|c|c|c|c|c|c|}
\hline & (7) & (8) & (9) & (10) & (11) & (12) \\
\hline & Score1 & Score2 & Score3 & Score1 & Score2 & Score3 \\
\hline \multirow[t]{2}{*}{ DID-advance2 } & 0.0362 & 0.0470 & 0.0140 & & & \\
\hline & $(1.38)$ & (1.69) & $(0.37)$ & & & \\
\hline \multirow[t]{2}{*}{ DID-advance 3} & & & & 0.0217 & 0.0327 & 0.0028 \\
\hline & & & & $(0.93)$ & $(1.32)$ & $(0.09)$ \\
\hline \multirow[t]{2}{*}{ Scale } & $-0.0910 * * *$ & $-0.0962 * * *$ & $-0.1074 * * *$ & $-0.0897 * * *$ & $-0.0948 * * *$ & $-0.1064 * * *$ \\
\hline & $(-4.78)$ & $(-4.79)$ & $(-4.16)$ & $(-4.70)$ & $(-4.71)$ & $(-4.12)$ \\
\hline \multirow[t]{2}{*}{ Leverage } & $-0.0035 * * *$ & $-0.0040 * * *$ & $-0.0045^{* * *}$ & $-0.0035 * * *$ & $-0.0040 * * *$ & $-0.0045 * * *$ \\
\hline & $(-4.42)$ & $(-4.88)$ & $(-4.98)$ & $(-4.44)$ & $(-4.90)$ & $(-4.98)$ \\
\hline \multirow[t]{2}{*}{ Fes } & $0.0048 * * *$ & $0.0049 * * *$ & $0.0063 * * *$ & $0.0049 * * *$ & $0.0050 * * *$ & $0.0063 * * *$ \\
\hline & $(4.12)$ & $(3.91)$ & $(3.85)$ & $(4.15)$ & $(3.95)$ & $(3.88)$ \\
\hline \multirow[t]{2}{*}{$\mathrm{TC}$} & 0.0554 & 0.0584 & -0.0005 & 0.0537 & 0.0565 & -0.0015 \\
\hline & $(1.01)$ & $(1.04)$ & $(-0.01)$ & $(0.98)$ & $(1.00)$ & $(-0.02)$ \\
\hline \multirow[t]{2}{*}{ MBI } & $0.1065^{* *}$ & $0.1104 * *$ & $0.1857 * *$ & $0.1066^{* *}$ & $0.1105^{* *}$ & $0.1857 * *$ \\
\hline & $(2.00)$ & $(2.00)$ & $(2.58)$ & $(2.00)$ & (1.99) & $(2.56)$ \\
\hline \multirow[t]{2}{*}{ EPI } & 0.0016 & 0.0034 & 0.0054 & 0.0013 & 0.0031 & 0.0052 \\
\hline & $(0.23)$ & $(0.50)$ & $(0.66)$ & $(0.19)$ & $(0.46)$ & $(0.63)$ \\
\hline \multirow[t]{2}{*}{ cons } & -0.2219 & -0.2397 & -0.3910 & -0.2149 & -0.2306 & -0.3883 \\
\hline & $(-1.01)$ & $(-1.04)$ & $(-1.47)$ & $(-0.97)$ & $(-1.00)$ & $(-1.46)$ \\
\hline Year & Control & Control & Control & Control & Control & Control \\
\hline Individual & Control & Control & Control & Control & Control & Control \\
\hline $\mathrm{N}$ & 486 & 486 & 486 & 486 & 486 & 486 \\
\hline $\mathrm{R}^{2}$ & 0.275 & 0.284 & 0.250 & 0.273 & 0.282 & 0.250 \\
\hline
\end{tabular}

Notes: $\mathrm{t}$ statistics in parentheses. ${ }^{* *},{ }^{* *}$, and $*$ denote the statistical significance at the $0.01,0.05$, and 0.10 levels, respectively. 
Table 6. Regional Heterogeneity Analysis (East, Mid-West).

\begin{tabular}{|c|c|c|c|c|c|c|}
\hline & \multicolumn{3}{|c|}{ East } & \multicolumn{3}{|c|}{ Mid-West } \\
\hline & (13) & (14) & (15) & (16) & (17) & (18) \\
\hline & Score1 & Score2 & Score3 & Score1 & Score2 & Score3 \\
\hline \multirow[t]{2}{*}{ DID } & $0.0917 * *$ & $0.1016^{* *}$ & $0.1433 * * *$ & 0.0306 & 0.0401 & 0.0801 \\
\hline & $(2.34)$ & $(2.47)$ & $(2.85)$ & $(0.53)$ & $(0.67)$ & $(1.01)$ \\
\hline \multirow[t]{2}{*}{ Scale } & $-0.1418 * * *$ & $-0.1478 * * *$ & $-0.1555 * * *$ & -0.0092 & -0.0174 & -0.0434 \\
\hline & $(-5.76)$ & $(-5.72)$ & $(-4.92)$ & $(-0.30)$ & $(-0.55)$ & $(-1.04)$ \\
\hline \multirow[t]{2}{*}{ Leverage } & $-0.0022 *$ & $-0.0025^{*}$ & $-0.0033 * *$ & $-0.0040 * * *$ & $-0.0045 * * *$ & $-0.0051 * * *$ \\
\hline & $(-1.78)$ & $(-1.93)$ & $(-2.05)$ & $(-4.53)$ & $(-4.92)$ & $(-4.25)$ \\
\hline \multirow[t]{2}{*}{ Fes } & $0.0038 * *$ & $0.0042 * *$ & $0.0042 *$ & $0.0035^{*}$ & 0.0030 & $0.0065^{* *}$ \\
\hline & $(2.01)$ & $(2.12)$ & $(1.70)$ & $(1.92)$ & (1.59) & $(2.58)$ \\
\hline \multirow[t]{2}{*}{$\mathrm{TC}$} & 0.0654 & 0.0632 & 0.0325 & -0.0564 & -0.0251 & -0.1723 \\
\hline & $(0.98)$ & $(0.90)$ & $(0.38)$ & $(-0.54)$ & $(-0.23)$ & $(-1.21)$ \\
\hline \multirow[t]{2}{*}{ MBI } & $0.1794 * * *$ & $0.1934 * * *$ & $0.2391 * * *$ & 0.1015 & 0.0727 & $0.2503 *$ \\
\hline & $(2.67)$ & $(2.74)$ & $(2.77)$ & (1.09) & $(0.76)$ & (1.97) \\
\hline \multirow[t]{2}{*}{ EPI } & 0.0055 & 0.0066 & 0.0067 & -0.0025 & 0.0005 & 0.0062 \\
\hline & $(0.60)$ & $(0.69)$ & $(0.57)$ & $(-0.29)$ & $(0.05)$ & $(0.53)$ \\
\hline \multirow[t]{2}{*}{ cons } & $-0.7921 * * *$ & $-0.8765 * * *$ & $-1.0288 * * *$ & 0.3499 & 0.4270 & 0.2542 \\
\hline & $(-2.79)$ & $(-2.95)$ & $(-2.83)$ & $(1.21)$ & $(1.44)$ & $(0.65)$ \\
\hline Year & control & control & control & control & control & control \\
\hline Individual & control & control & control & control & control & control \\
\hline $\mathrm{N}$ & 270 & 270 & 270 & 216 & 216 & 216 \\
\hline $\mathrm{R}^{2}$ & 0.359 & 0.367 & 0.319 & 0.173 & 0.179 & 0.185 \\
\hline
\end{tabular}

Notes: $\mathrm{t}$ statistics in parentheses. $* * *, * *$, and $*$ denote the statistical significance at the $0.01,0.05$, and 0.10 levels, respectively.

is that state-owned enterprises also undertake many social functions while operating enterprises. In other words, after the state-owned enterprises obtain profits through production and operation, they must use part of the profits for some social functions, while non-stateowned enterprises rarely have this problem. Because of the different forms of enterprise ownership, is there any difference in the impact of energy management system certification on corporate performance? Based on this, this section discusses the ownership heterogeneity of the impact of energy management system certification on enterprise performance. The specific results are shown in Table 7.

By comparing the model (19), (20), (21) and model (22), (23), (24), it can be seen that the energy management system certification of state-owned enterprises has a significant promoting effect on enterprise performance, while the energy management system certification of non-state-owned enterprises has a inhibitory effect on enterprise performance, but it is not statistically significant. From the influence coefficient, the impact of energy management system of state-owned enterprises on enterprise performance is significantly higher than that of non-state-owned enterprises. In China, state-owned enterprises are subject to stricter government supervision. As environmental protection policies become more and more stringent, state-owned enterprises are subject to strong government intervention. Therefore, the implementation of the energy management system has continuously reduced the energy costs of stateowned enterprises and reduced pollution payments. Thereby promoting a significant improvement in the performance of state-owned enterprises. Compared with state-owned enterprises, it is more difficult for non-state-owned enterprises to obtain financial resources. The implementation of the EnMS squeezes limited resources, and the non-state-owned enterprises have a weak willingness to implement the EnMS, and the implementation effect is poor, which has a restraining effect. The statistical result is not significant. 
Table 7. Ownership Heterogeneity Analysis (State-Owned, Non-State-Owned).

\begin{tabular}{|c|c|c|c|c|c|c|}
\hline & \multicolumn{3}{|c|}{ State-Owned Enterprises } & \multicolumn{3}{|c|}{ Non-State-Owned Enterprises } \\
\hline & (19) & $(20)$ & $(21)$ & $(22)$ & (23) & $(24)$ \\
\hline & Score1 & Score2 & Score3 & Score1 & Score2 & Score3 \\
\hline DID & $0.1285^{* * *}$ & $0.1465 * * *$ & $0.1780 * * *$ & -0.0388 & -0.0575 & -0.0246 \\
\hline & $(3.95)$ & $(4.36)$ & $(4.18)$ & $(-0.46)$ & $(-0.64)$ & $(-0.22)$ \\
\hline Scale & -0.0285 & -0.0316 & $-0.0801 * * *$ & -0.0434 & -0.0264 & 0.0255 \\
\hline & $(-1.30)$ & $(-1.40)$ & $(-2.80)$ & $(-0.63)$ & $(-0.36)$ & $(0.27)$ \\
\hline Leverage & $-0.0024 * * *$ & $-0.0029 * * *$ & $-0.0044 * * *$ & $-0.0031 *$ & $-0.0034 *$ & -0.0029 \\
\hline & $(-2.86)$ & $(-3.39)$ & $(-4.03)$ & $(-1.79)$ & $(-1.81)$ & $(-1.22)$ \\
\hline Fes & $0.0041 * * *$ & $0.0042 * * *$ & $0.0064 * * *$ & -0.0004 & -0.0018 & -0.0078 \\
\hline & $(3.15)$ & $(3.12)$ & $(3.75)$ & $(-0.09)$ & $(-0.37)$ & $(-1.28)$ \\
\hline $\mathrm{TC}$ & -0.1438 & -0.1407 & -0.0508 & 0.1148 & 0.1237 & 0.0495 \\
\hline & $(-1.50)$ & $(-1.42)$ & $(-0.41)$ & $(1.52)$ & (1.54) & $(0.49)$ \\
\hline MBI & $0.2631 * * *$ & $0.2644 * * *$ & $0.2247 * *$ & 0.0271 & 0.0207 & 0.0663 \\
\hline & $(3.01)$ & $(2.93)$ & (1.97) & $(0.29)$ & $(0.21)$ & $(0.54)$ \\
\hline EPI & -0.0038 & -0.0014 & -0.0010 & 0.0213 & 0.0187 & 0.0337 \\
\hline & $(-0.58)$ & $(-0.21)$ & $(-0.12)$ & $(1.24)$ & $(1.02)$ & (1.47) \\
\hline cons & $-0.5772 * *$ & $-0.5968 * *$ & $-0.6241 * *$ & -0.6741 & $-0.9060^{*}$ & $-1.4455^{* *}$ \\
\hline & $(-2.52)$ & $(-2.52)$ & $(-2.08)$ & $(-1.40)$ & $(-1.76)$ & $(-2.23)$ \\
\hline Year & control & control & control & control & control & control \\
\hline Individual & control & control & control & control & control & control \\
\hline $\mathrm{N}$ & 378 & 378 & 378 & 108 & 108 & 108 \\
\hline $\mathrm{R}^{2}$ & 0.298 & 0.314 & 0.300 & 0.329 & 0.330 & 0.246 \\
\hline
\end{tabular}

Notes: $\mathrm{t}$ statistics in parentheses. $* * * * *$, and $*$ denote the statistical significance at the $0.01,0.05$, and 0.10 levels, respectively.

\section{Conclusion}

This study aims to explore the impact of energy management systems on enterprise performance. Based on the empirical results of 54 large iron and steel enterprises in China, we find that the implementation of energy management system has a significant effect on enterprise performance. In particular, based on regional heterogeneity and ownership heterogeneity, this study further analyzes the impact of energy management system on enterprise performance.

This study mainly made the following contributions. First of all, the current conceptual and empirical studies on the impact of energy management systems are very limited. As far as we know, recent quantitative studies have paid more attention to the benefits of adopting environmental management systems (EMS) $[50,51]$, and energy management system standards are issued later than environmental management system standards, and the recognition is not high. Researchers pay less attention to the impact of EnMS on enterprise performance. More importantly, although the energy management system (EnMS) and the environmental management system (EMS) are closely linked, the steel industry, as an industry with high energy costs, is more appropriate to study EnMS.

Secondly, considering that the impact of EnMS on enterprise performance may vary with different conditions, this study further explores the regional heterogeneity and ownership heterogeneity. Specifically, the promotion effect of the implementation of EnMS in the eastern region is significantly higher than that in the central and western regions, because the competition among enterprises in the eastern region is more intense and the government supervision has become stricter. These reasons promote enterprises to actively implement EnMS, so the promotion effect is better. The impact of the implementation of EnMS in state-owned enterprises is significantly higher than that in non-state-owned enterprises. The state-owned enterprises are strongly intervened by the government, and the environmental regulations are stricter. 
Therefore, the implementation of EnMS makes the state-owned enterprises reduce the pollution payment and reduce the energy cost, thereby promoting a significant improvement in the performance of stateowned enterprises.

Finally, the results of this study show that enterprises can not only obtain economic benefits but also environmental benefits by implementing EnMS. Moreover, the study further found that the positive impact of the EnMS on economic performance is greater than the impact on environmental performance. Because managers are more likely to join EnMS for economic reasons. The implementation of EnMS can improve the efficiency of energy utilization, reduce energy consumption, and improve the level of enterprise energy management. Let managers see the benefits of EnMS for enterprises, so that managers can change their minds. The leader of an enterprise should clarify the importance of EnMS to energy conservation, to the development of the enterprise, and to the environment, so that managers can really pay attention to it.

Although this study provides valuable findings on the effectiveness of energy management system, it also has some limitations and provides opportunities for future research. First, in order to pay attention to the special impact of the energy management system, the research sample selected a single country and industry as the empirical basis, which limits the generality of the results.

\section{Acknowledgements}

We are grateful for the financial support of National Natural Science Fund (Project No. 71673022) and the Fundamental Research Funds for the Central Universities (Project No. 06106242).

\section{Conflicts of Interest}

The authors declare no conflict of interest.

\section{References}

1. BP G. BP Statistical Review of World Energy June 2011. In 2011.

2. SCHULZE M., NEHLER H., OTTOSSON M., THOLLANDER P. Energy management in industry - a systematic review of previous findings and an integrative conceptual framework. J Clean Prod. 112, 3692, 2016.

3. CHEN L., HE F., ZHANG Q., JIANG W., WANG J. Twostage efficiency evaluation of production and pollution control in Chinese iron and steel enterprises. J Clean Prod. 165, 611, 2017.

4. WU H., LV K., LIANG L., HU H. Measuring performance of sustainable manufacturing with recyclable wastes: A case from China's iron and steel industry. Omega. 66, 38, 2017.
5. JONG P.D., PAULRAJ A., BLOME C. The Financial Impact of ISO 14001 Certification: Top-Line, BottomLine, or Both? J Bus Ethics. 119, 131, 2014.

6. CAÑÓN-DE-FRANCIA J., GARCÉS-AYERBE C. ISO 14001 Environmental Certification: A Sign Valued by the Market? Environmental and Resource Economics. 44, 245, 2009.

7. TO W.M., LEE P.K.C. Diffusion of ISO 14001 environmental management system: global, regional and country-level analyses. J Clean Prod. 66, 489, 2014.

8. BOIRAL O., GUILLAUMIE L., HERASSAIZARBITORIA I., TAYO T.C.V. Adoption and Outcomes of ISO 14001: A Systematic Review. Int J Manage Rev. 20, 411, 2018.

9. SOUSALIRA J.M., SALGADO E.G., BEIJO L.A. Which factors does the diffusion of ISO 50001 in different regions of the world is influenced? J Clean Prod. 226, 759, 2019.

10. BÖTTCHER C., MÜLLER M. Insights on the impact of energy management systems on carbon and corporate performance. An empirical analysis with data from German automotive suppliers. J Clean Prod. 137, 1449, 2016.

11. MARIMON F., CASADESÚS M. Reasons to Adopt ISO 50001 Energy Management System. Sustainability-Basel. 9, 1740, 2017.

12. BUNSE K., VODICKA M., SCHÖNSLEBEN P., BRÜLHART M., ERNST F.O. Integrating energy efficiency performance in production management - gap analysis between industrial needs and scientific literature. J Clean Prod. 19, 667, 2011.

13. STENQVIST C., NILSSON L.J. Energy efficiency in energy-intensive industries -an evaluation of the Swedish voluntary agreement PFE. Energy Efficiency. 5, 225, 2012.

14. WEIDONG F., WEI H., KUNYA W., HUOYIN L., ZHIHAO J. A Method to Establish and Run Management System for Energy. Energy Procedia. 5, 1584-1588, 2011.

15. ANTÓNIO DA SILVA GONÇALVES V., MIL-HOMENS DOS SANTOS F.J. Energy management system ISO 50001:2011 and energy management for sustainable development. Energy Policy. 133, 110, 2019.

16. MCKANE A., THERKELSEN P., SCODEL A., RAO P., AGHAJANZADEH A., HIRZEL S., ZHANG R., PREM R., FOSSA A., LAZAREVSKA A.M. Predicting the quantifiable impacts of ISO 50001 on climate change mitigation. Energy Policy. 107, 278, 2017.

17. WORRELL E., LAITNER J.A., RUTH M., FINMAN H. Productivity benefits of industrial energy efficiency measures. Energy. 28, 1081, 2003.

18. PELSER W.A., VOSLOO J.C., MATHEWS M.J. Results and prospects of applying an ISO 50001 based reporting system on a cement plant. J Clean Prod. 198, 642, 2018.

19. ATES S.A., DURAKBASA N.M. Evaluation of corporate energy management practices of energy intensive industries in Turkey. Energy. 45, 81, 2012.

20. PORZIO G.F., FORNAI B., AMATO A., MATARESE N., VANNUCCI M., CHIAPPELLI L., COLLA V. Reducing the energy consumption and $\mathrm{CO}_{2}$ emissions of energy intensive industries through decision support systems - An example of application to the steel industry. Apply Energy. 112, 818, 2013.

21. MARIMON F., CASADESÚS M. Reasons to Adopt ISO 50001 Energy Management System. Sustainability-Basel. 9, 1740, 2017.

22. HASSAN KHATTAK S., OATES M., GREENOUGH R. Towards Improved Energy and Resource Management in Manufacturing. Energies. 11, 1006, 2018. 
23. MARZBAND M., SUMPER A., DOMINGUEZ-GARCIA J.L., GUMARA-FERRET R. Experimental validation of a real time energy management system for microgrids in islanded mode using a local day-ahead electricity market and MINLP. Energy Conversion \& Management. 76, 314, 2013.

24. BÖTTCHER C., MÜLLER M. Insights on the impact of energy management systems on carbon and corporate performance. An empirical analysis with data from German automotive suppliers. J Clean Prod. 137, 1449, 2016.

25. LEE D., CHENG C.C. Energy savings by energy management systems: A review. Renewable \& Sustainable Energy Reviews. 56, 760, 2016.

26. VIKHOREV K., GREENOUGH R., BROWN N. An advanced energy management framework to promote energy awareness. J Clean Prod. 43, 103, 2013.

27. WEITZEL T., GLOCK C.H. Energy Management for Stationary Electric Energy Storage Systems: A Systematic Literature Review. Eur J Oper Res. S965334451, 2017.

28. CHIU T.Y., LO S.L. Establishing an Integration-EnergyPractice Model to Improve Energy Efficiency in ISO 50001 Energy Management Systems: A Case Study for a Networking Products Company. Journal of Quality. 22, 15, 2015.

29. NEVES F.D.O., SALGADO E.G., BEIJO L.A. Analysis of the Environmental Management System based on ISO 14001 on the American continent. J Environ Manage. 199, 251, 2017.

30. JOVANOVIĆ B., FILIPOVIĆ J. ISO 50001 standardbased energy management maturity model-proposal and validation in industry. J Clean Prod. 112, 2744, 2016.

31. TRIANNI A., CAGNO E., THOLLANDER P., BACKLUND S. Barriers to industrial energy efficiency in foundries: a European comparison. J Clean Prod. 40, 161, 2013.

32. GORDIĆ D., BABIĆ M., JOVIČIĆ N., ŠUŠTERŠIČ V., KONČALOVIĆ D., JELIĆ D. Development of energy management system - Case study of Serbian car manufacturer. Energy Convers Manage. 51, 2783, 2010.

33. VELÁZQUEZ D., GONZÁLEZ-FALCÓN R., PÉREZLOMBARD L., MARINA GALLEGO L., MONEDERO I., BISCARRI F. Development of an energy management system for a naphtha reforming plant: A data mining approach. Energy Convers Manage. 67, 217, 2013.

34. RAFAEL URIARTE-ROMERO M.G.E.V., CEBALLOSCORRAL A.J., AGHAJANZADEH A. Methodology for the Successful Integration of an Energy Management System to an Operational Environmental System. Sustainability-Basel. 9, 1304, 2017.

35. PHAM T.H.H. Energy management systems and market value: Is there a link? Econ Model. 46, 70, 2015.

36. RUDBERG M., WALDEMARSSON M., LIDESTAM H. Strategic perspectives on energy management: A case study in the process industry. Apply Energy. 104, 487, 2013.
37. ROLAND, JOCHEM, PHILLIP, KARCHER. Success factors and organizational approaches for the implementation of energy management systems according to ISO 50001. The TQM Journal 2015.

38. MCKANE A.D.D.M. Thinking Globally: How ISO 50001 - Energy Management can make industrial energy efficiency standard practice. Earnest Orlando Lawrence Berkeley National. 1, 5, 2009.

39. WAGNER M. Innovation and competitive advantages from the integration of strategic aspects with social and environmental management in European firms. Bus Strategy Environ. 2009.

40. ALI W., FRYNAS J.G., MAHMOOD Z. Determinants of Corporate Social Responsibility (CSR) Disclosure in Developed and Developing Countries: A Literature Review. Corp Soc Resp Env Ma. 24, 273, 2017.

41. VIKHOREV K., GREENOUGH R., BROWN N. An advanced energy management framework to promote energy awareness. J Clean Prod. 43, 103, 2013.

42. TSENG Y., LEE D., LIN C., CHANG C. The Energy Savings and Environmental Benefits for Small and Medium Enterprises by Cloud Energy Management System. Sustainability-Basel. 8, 531, 2016.

43. JOVANOVIĆ B., FILIPOVIĆ J., BAKIĆ V. Energy management system implementation in Serbian manufacturing - Plan-Do-Check-Act cycle approach. J Clean Prod. 162, 1144, 2017.

44. CHRYSIKOPOULOS S., CHOUNTALAS P. Integrating energy and environmental management systems to enable facilities to qualify for carbon funds. Energy Environ-Uk. 29, 938, 2018.

45. CHRISTOFFERSEN L.B., LARSEN A., TOGEBY M. Empirical analysis of energy management in Danish industry. J Clean Prod. 14, 516, 2006.

46. TANG Z., TANG J. Stakeholder Corporate Social Responsibility Orientation Congruence, Entrepreneurial Orientation and Environmental Performance of Chinese Small and Medium-sized Enterprises. Brit J Manage. 29, 634, 2018.

47. WANG G., LI K.X., XIAO Y. Measuring marine environmental efficiency of a cruise shipping company considering corporate social responsibility. Mar Policy. 99, 140, 2019.

48. CHEN L., HE F., ZHANG Q., JIANG W., WANG J. Twostage efficiency evaluation of production and pollution control in Chinese iron and steel enterprises. J Clean Prod. 165, 611, 2017.

49. XU X., ZENG S., CHEN H. Signaling good by doing good: How does environmental corporate social responsibility affect international expansion? Bus Strategy Environ. 27, 946, 2018.

50. ÓN-DE-FRANCIA J.C., GARCÉS-AYERBE C. ISO 14001 Environmental Certification: A Sign Valued by the Market? Environ Res Econ. 44, 245, 2009.

51. JONG P.D., PAULRAJ A., BLOME C. The Financial Impact of ISO 14001 Certification: Top-Line, BottomLine, or Both? J Bus Ethics. 119, 131, 2014. 